\title{
APPLICATION OF REMOTE SENSING FOR HIGH MOUNTAIN ECOSYSTEM CONDITION ASSESSMENT (SOUTH WEST RILA MOUNTAIN - BULGARIA)
}

\author{
Kostadin Katrandzhiev
}

\begin{abstract}
On basis of multispectral satellite data from Sentinel 2, an assessment of high mountain ecosystems condition is executed in selected territories of South West Rila Mountain. To define their actual condition, values of Normalized Difference Vegetation Index (NDVI), Normalized Difference Water Index (NDWI) and Normalized Differential Greenness Index (NDGI) were computed. The obtained values of these indices are presented as graphic images and thematic maps showing spatial distribution of the actual condition of high mountain ecosystems in the studied territories of Rila Mountain. The obtained results can be used for further assessment of ecosystem services provided by described ecosystems.
\end{abstract}

Key words: forest ecosystems, remote sensing, NDVI, NDWI, NDGI

\section{INTRODUCTION}

High mountain ecosystems (HME) are believed to be an indicator of climate changes both on global and regional scale. The alleged vulnerability of HME to environmental changes makes them an object of high scientific interest in terms of gaining knowledge about their functioning in changing environments. The assessment of the actual condition of these ecosystems is also of high importance for the elaboration and implementation of appropriate policies for good management practices which could enhance ecosystem resilience and adaptation to climate change. There are methodologies for assessment of the state of different ecosystem types developed both on European $[1,2,3]$ and national level [4] including a methodology for assessment and mapping of woodland and forest ecosystem conditions and their services.

The using of remote sensing methods is a relatively new approach which provides greater opportunities for ecosystem analyses and condition assessment on the landscape level. This gives them some advantage over the ground methods, but it is the combination of both that increases research objectivity [5]. A number of indices were elaborated for analyzing ecosystem functional condition. They were mostly designed for forest health assessment [6]. Using satellite data for computing of different indices allows the assessment of specific characteristics of ecosystem functionality and thus gives new opportunities for analyses and interpretation of HME (and specifically forest ecosystems) [7].
The aim of the current study was to assess the changes in the functional condition of high mountain ecosystems in a selected territory of Rila Mountain by means of remote sensing methods based on NDVI, NDWI and NDGI.

\section{MATERIALS AND METHODS}

The study was carried out on a territory which was selected based on pre- set criteria i.e. to encompass more than one vegetation type, to cover a territory corresponding to definition of high mountain habitat including treeline ecotone which marks the transition from closed tall forest to the alpine zone [8] and to be easily accessible. The selected study area is located in the South West parts of Rila Mountain and includes parts of the lands of 7 populated places (Bistritsa, Gorno and Dolno Osenovo, Bachevo, Godlevo, Dobarsko and Belitsa) and also Parangalitsa Reserve with overall area of 9296 ha. The highest point of the study area is Ezernik peak $(2485 \mathrm{~m})$. Three main vegetation types were presented woodland and forests, shrubs and grasslands which form the physiognomy of the ecosystem.

In an attempt to assess the condition of the HME for the relatively short period from 02.08.2017 to 27.08.2017 a methodology was used including remote sensing data - multispectral satellite data from sensor MSI (MultiSpectral Instrument) Sentinel 2 with high spatial, spectral and radiometric resolution (Copernicus - ESA). The data used is presented in table 1. Based on this data NDVI, NDWI and NDGI $[9,10,11,12]$ indices were computed.

Table 1. Data sources used for indices calculation

\begin{tabular}{|c|c|c|}
\hline № & Date & Sensor \\
\hline $\mathbf{1}$ & 02.08 .2017 & MSI Sentinel 2 \\
\hline $\mathbf{2}$ & 27.08 .2017 & MSI Sentinel 2 \\
\hline
\end{tabular}




\subsection{Data analysis}

1.1.1. NDVI is an index showing the condition of biomass related to its functioning and indirectly connected to the photosynthesis process. It is computed by the following formula:

$$
N D V I=\frac{R_{\text {nir }}-R_{\text {red }}}{R_{\text {nir }}+R_{\text {red }}}
$$

where $R_{\text {nir }}, R_{\text {red }}$ are the reflectance coefficients in near infrared and red range of the electromagnetic specter.

1.1.2. NDWI is an index showing the vegetation canopy moisture content calculated using the next formula:

$$
N D W I=\frac{R_{\text {nir }}-R_{\text {mir }}}{R_{\text {nir }}+R_{\text {mir }}}
$$

where $R_{\text {nir }}, R_{\text {mir }}$ are the reflectance coefficients in near infrared and middle infrared range of the electromagnetic specter.

1.1.3. NDGI - using a Greenness component the index expresses quantitatively the positive and negative values during small increment of vegetation process. It is defined using the following formula:

$$
N D G I=\frac{G R_{n}\left(t_{2}\right)-G R_{n}\left(t_{1}\right)}{\left|G R_{n}\left(t_{2}\right)\right|+\left|G R_{n}\left(t_{1}\right)\right|}
$$

where: $G R_{n}\left(t_{1}\right)$ and $G R_{n}\left(t_{2}\right)$ - represent respectively the normalized values of the Greenness components at time points $t_{1}$ и $t_{2}$, and $\left|G R_{n}\left(t_{2}\right)\right|$ и $\left|G R_{n}\left(t_{1}\right)\right|$ represent the absolute values of the same components.

$G R_{n}\left(t_{1}\right)$ and $G R_{n}\left(t_{2}\right)$ are obtained based on the following equation:

$$
G R_{n}(t)=\frac{G R(t)-E\{G R(t)\}}{\operatorname{St} \cdot \operatorname{Dev}[G R(t)]}
$$

where $E\{G R(t)\}$ is the mean of $G R(t)$. In this case, for the normalized values is obtained $E\left\{G R_{n}(t)\right\}=$ 0 and St.Dev. $\left[E\left\{G R_{n}(t)\right]=1\right.$, which means that the values of $G R_{n}(t)$ are absolutely comparable (standardized), regardless on the sensor and time of satellite image capturing. Furthermore, the error stemming from external factor influences during satellite image capturing is significantly diminished.

\subsubsection{Climatic data}

In addition to the analysis of the indices data, an analysis of climatic characteristics (table 2) (fig. 1) - rain, evapotranspiration, solar radiation and mean temperature was carried out for the territory of the study area using the European climate database [13].

Table 2. Climate components values:

\begin{tabular}{|c|c|c|c|c|}
\hline Date & $\mathbf{R}(\mathbf{l} / \mathbf{m} \mathbf{2})$ & Evpt $(\mathbf{l} / \mathbf{m} \mathbf{2})$ & SR (kJ/m2) & T (0 C) \\
\hline $\mathbf{0 2 . 0 8 . 2 0 1 7}$ & 8 & 45 & 24.5 & 20 \\
\hline $\mathbf{2 7 . 0 8 . 2 0 1 7}$ & $19-20$ & 37 & 23 & 16 \\
\hline
\end{tabular}

\section{RESULTS AND DISCUSSION}

After NDVI data processing for the studied period of time (02.08 - 27.08.2017), a decrease in areas with high values of the index was observed at the end of the period. Mostly, this was true for the transition territories to the alpine zone as well as for separate areas located at lower elevation but to a less degree.

A similar trend with above mentioned was observed for the NDWI data within the same time range. The areas with high values of NDWI diminish compared to those with low values of the index for time period.

As regards to the NDGI index for the same time interval, the results confirmed the observed tendency of decrease in areas with high values of the index probably at the expense of increasing areas with lower values at the end of the studied period.

The data interpretation from the indices was based on the analysis of climate components. The indices themselves were used for the condition assessment of the selected HME. That is why an analysis of the interconnections between climate components and indices NDVI, NDWI and NDGI was made for the same period of time (02.08. 27.08.2017).

Climate components values (Fig. 1) at the beginning of the period showed relatively small amount of rainfalls $\left(81 / \mathrm{m}^{2}\right)$ compared to the rainfalls at the end of the period $\left(19-20 \mathrm{l} / \mathrm{m}^{2}\right)$ and higher levels of evapotranspiration $\left(45 \mathrm{l} / \mathrm{m}^{2}\right)$ at the beginning and lower levels towards the end of the period $\left(37 \mathrm{1} / \mathrm{m}^{2}\right)$. Initially the solar radiation parameter has values $\left(24.5 \mathrm{~kJ} / \mathrm{m}^{2}\right)$ which are higher than the subsequent ones $\left(23 \mathrm{~kJ} / \mathrm{m}^{2}\right)$. This could explain the higher levels of evapotranspiration at the start of the studied period compared to the levels in its end. The same mutuality was observed in regards to the mean temperature which changed from $20^{\circ} \mathrm{C}$ at the starting period point $(02.08 .2017)$ to $16^{0} \mathrm{C}$ at the ending period point (27.08.2017). 


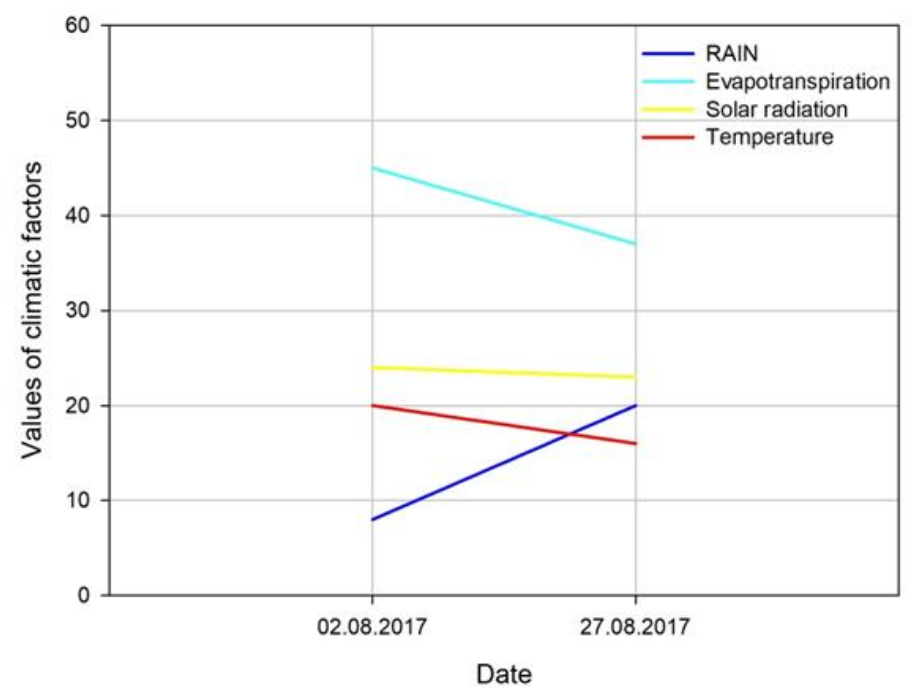

Fig. 1. Climate elements dynamic for the period $02.08-27.08 .2017$

A connection between climatic parameters and the selected indices was observed in which the initial values of the parameters were a prerequisite for higher mean NDVI values $(\sim 0.78)$. Respectively, the change of climatic elements' values at the end of period (27.08.2017) possibly determined index values decrease $(\sim 0.75)$. In other words the decrease of solar radiation parameter values together with temperature decrease logically could have led to lower levels of the evapotranspiration parameter independently of the significant rainfalls increase (from $81 / \mathrm{m}^{2}$ to $19-201 / \mathrm{m}^{2}$ ) which eventually were accumulated by soil and participated in the water balance of the whole forest ecosystem. Therefore the correlation between the decreased values of the parameters solar radiation, temperature and evapotranspiration and the NDVI was expressed in the lowering of photosynthetic activity of the vegetation. Spatially, at the beginning of the studied period (02.08.2017) the index values closer to 0 covered fewer territories (Fig. 2a). At the end of the period (27.08.2017) the values closer to 0 covered larger areas (Fig. 2b). Then the territories located mostly in the transition area to the alpine zone as well as separate areas in the lower parts of the studied object showed a trend of decreasing the NDVI values. This trend determined first photosynthesis demotion on these areas and second it determined the presence of vegetation cover other than trees - grassland and/or shrubs.
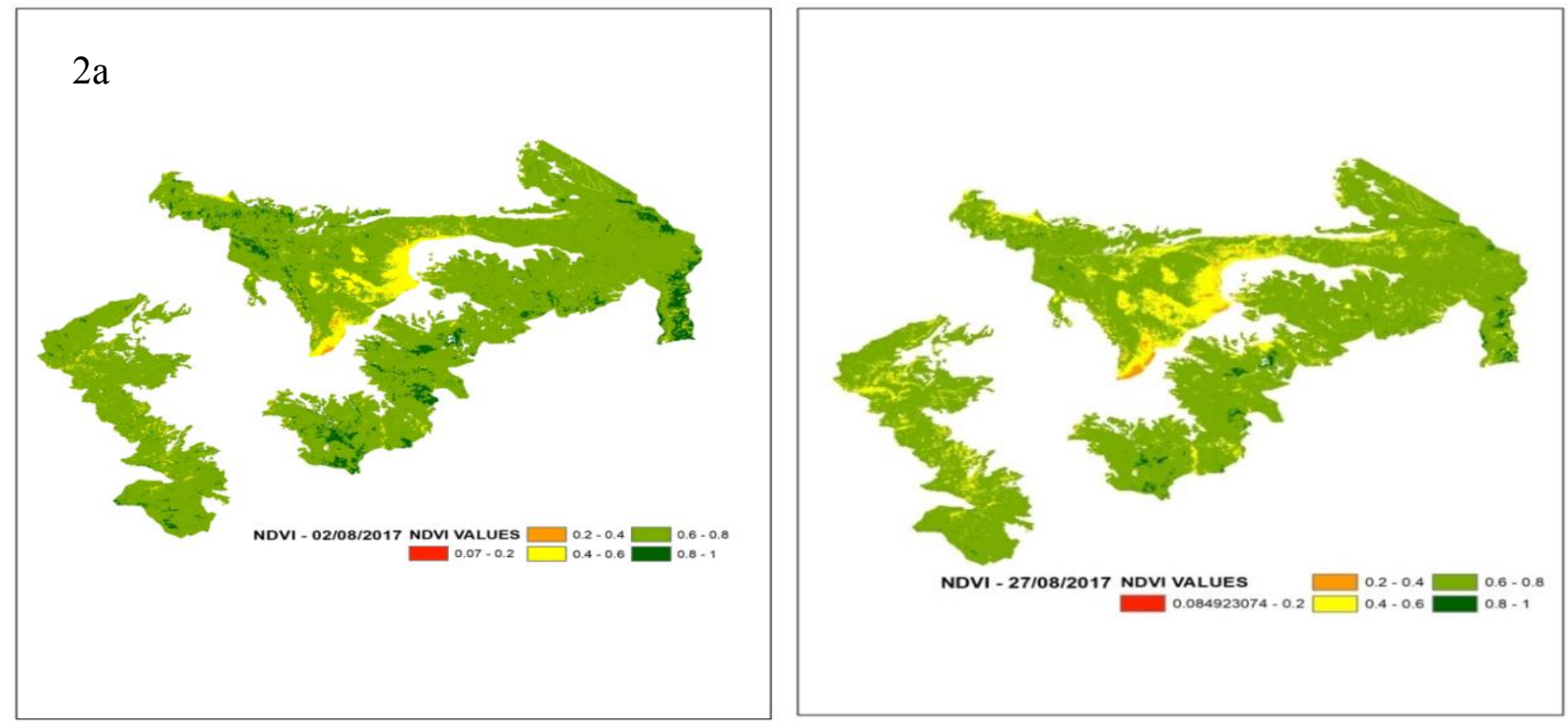

Fig. 2. Spatial distribution of NDVI for the period from 02.08. (a) to 27.08.2017 (b) 
All these findings were confirmed also from the results of the NDGI index (Fig. 3). Taking into account the changes that occurred in the green component of the vegetation, the NDGI analysis clearly outlined a tendency of enlargement of the territories with low index values $(-1 \div-0.2)$ towards the alpine zone for the period from 02.08.2017 to 27.08.2017.

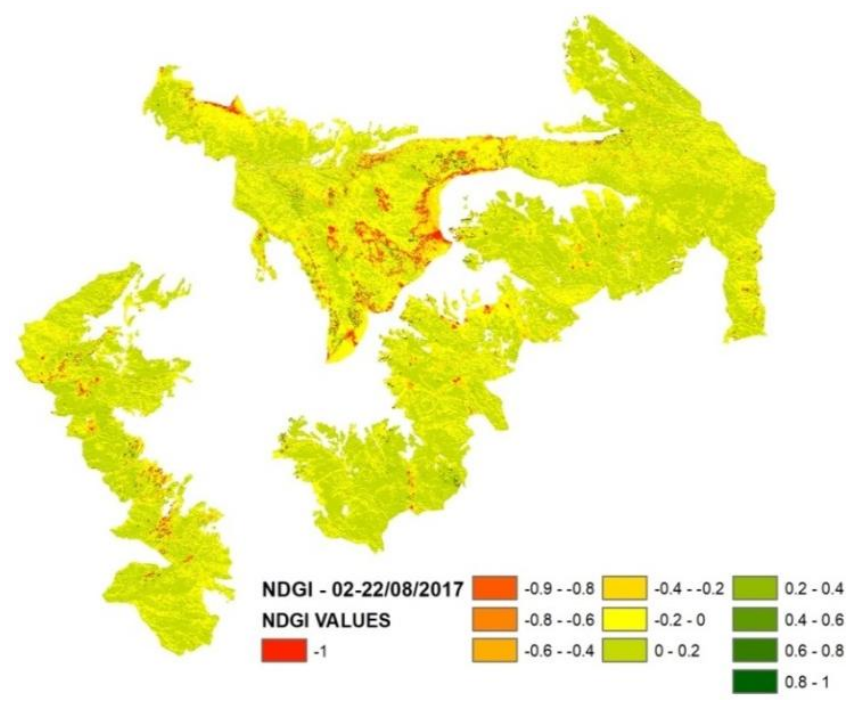

Fig. 3. Spatial distribution of NDGI for the period 02.08-27.08.2017

Readings around 0 denoted that the vegetation functioning i.e. photosynthesis remained unchanged (stable) for the studied time interval. Negative values $(<0)$ expressed some functional disturbance occurring in the vegetation. All other readings above 0 were interpreted as the presence of good photosynthetic activity of the vegetation. Again, the same transition zones and the separate areas in the lower parts of the study region had lowered values of NDGI. This also suggested the presence of different from forest vegetation type cover. In spatial terms, the NDWI values rangea from -0.2 to 0.75 among the studied area and the time period. The same trend of expansion the range of the transition territories towards the alpine zone as well as the separate areas on lower altitude which had NDWI values close to the minimum was established at the end of the period (Fig. 4a, b).
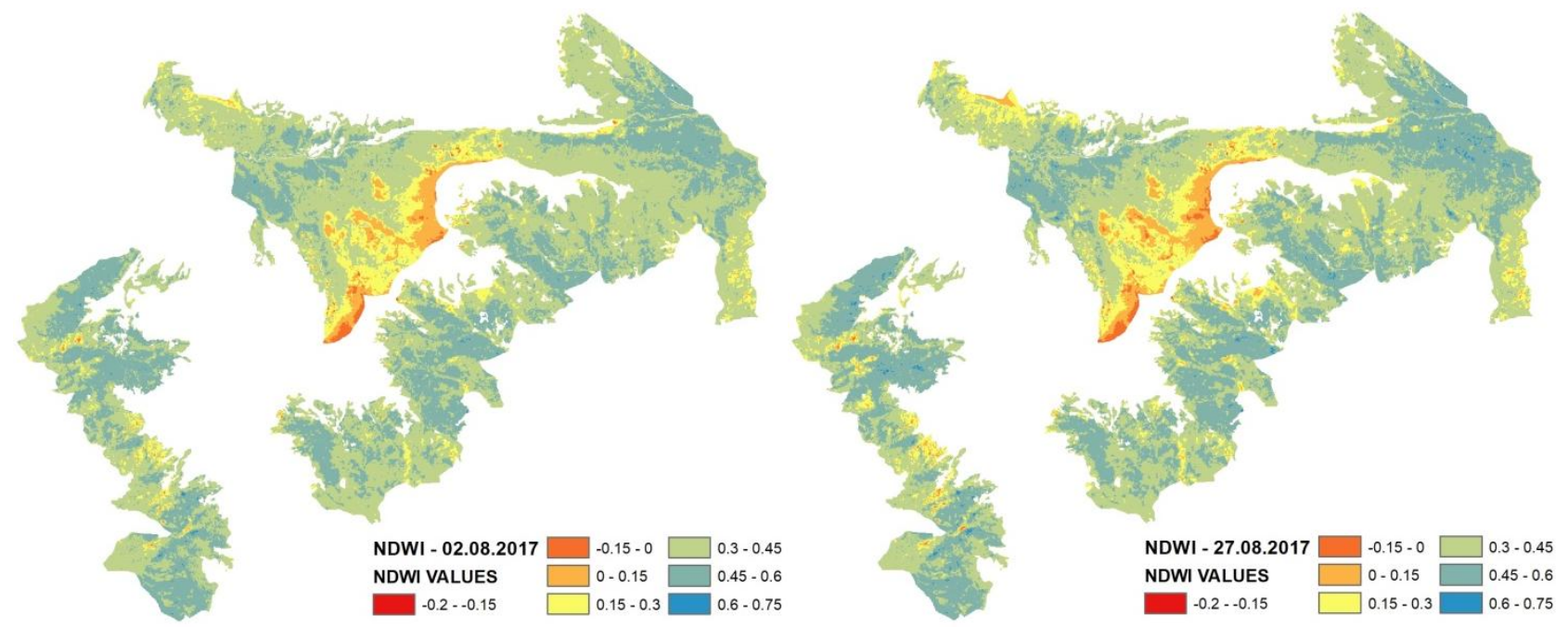

Fig. 4. Spatial distribution of NDWI in the study area for the period from 02.08 (a) to 27.08 .2017 (b)

Similarly, the areas with lower values of the indices NDVI and NDGI expanded in the locations covered with vegetation other than trees as to the date of 27.08.2017 which corresponds to the above observations concerning the NDWI index. 
To verify the NDWI values, territories covered with conifer forest vegetation were selected (Fig. 5a, b) first because of their physiological and functional

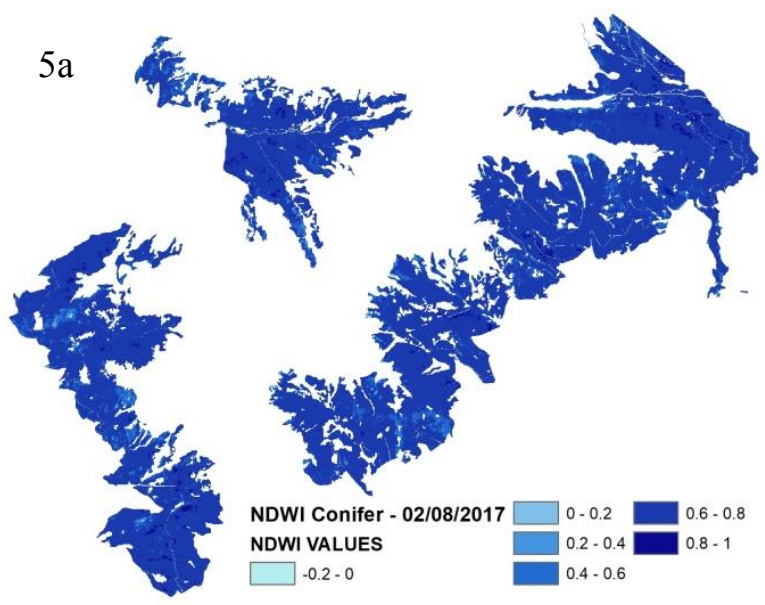

characteristics related to the ability of keeping their greenness throughout the year and second because of their dominant role in the study area.

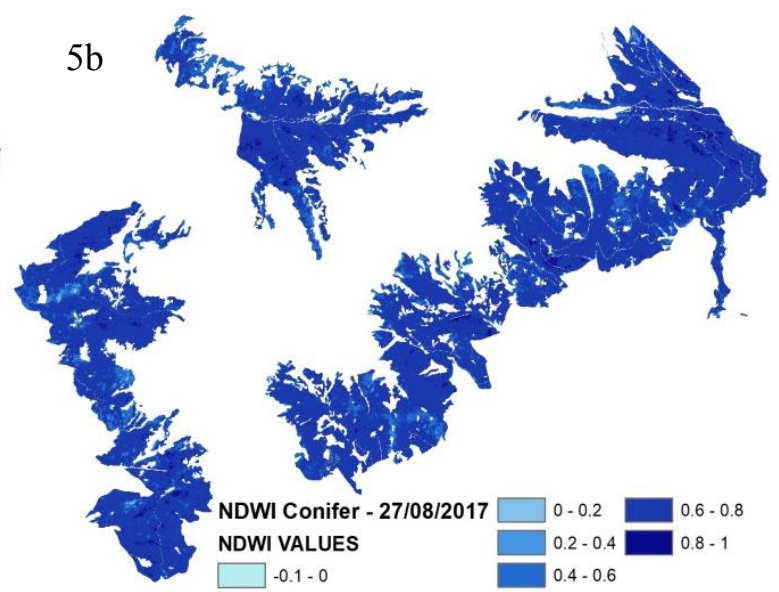

Fig. 5. Spatial distribution of NDWI in conifer forests for the period from 02.08 (a) to 27.08 .2017 (b)

Correlation analysis (equation; Fig. 6) was index values in the beginning of the studied period. carried out:

$N D W I_{27.08 .2017}=0.180+0.744 * N D W I_{02.08 .2017}$

where $N D W I_{27.08 .2017}$ are the index values from the end of the studied period and $N D W I_{02.08 .2017}$ are the

The correlation level is very high with correlation coefficient $\mathrm{R}^{2}=0.863$. In Fig. 6 the correlation dependency between NDWI values in the beginning and at the end of the period is shown.

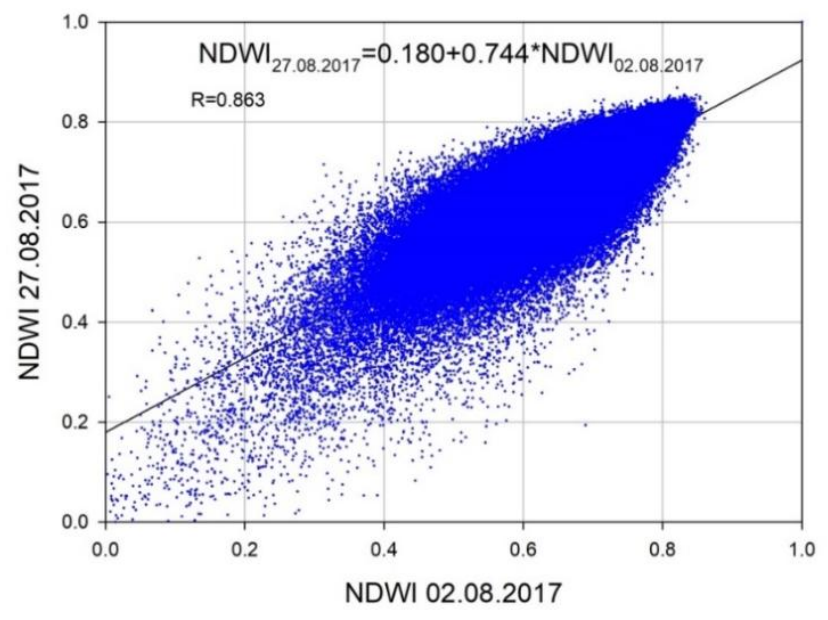

Fig. 6. Correlation diagram of NDWI values for 02.08 and 27.08.2017

The observed high correlation between the NDWI values at the beginning and at the end of the observed time interval strongly indicated sustainability of the photosynthetic process. This was most probably related to the resilience capacity of the type of forest vegetation (conifer) for which the NDWI was computed.

\section{CONCLUSION}

A methodological approach, based on remote sensing data and analyzes of climate components, was used to assess of the actual condition of HME in
South West Rila Mountain. The indices NDVI, NDWI and NDGI were used to characterize the condition of the ecosystems for a short time interval (02.08 - 27.08.2017). Interrelations between the climate components and indices were observed. As a whole, dynamics were observed in the treeline ecotone related to functional demotion of grassland territories in the transition to the alpine zone. In general, it was impossible to definitely conclude that the studied high mountain ecosystem was resilient to climate changes because of the short study period. 
The important conclusion is that the methodology used worked properly and it can be used for assessment of HME condition for longer periods of time.

\section{REFERENCES}

1. MAES Technical Report, EU, Mapping and Assessment of Ecosystems and their Services: An analytical framework for ecosystem assessments under Action 5 of the EU Biodiversity Strategy to 2020, 2013-067; ISBN 978-92-79-29369-6, doi: $10.2779 / 12398$

2. MAES Technical Report, EU, Mapping and Assessment of Ecosystems and their Services: Indicators for ecosystem assessments under Action 5 of the EU Biodiversity Strategy to 2020, 2014-080; ISBN 978-92-79-36161-6, doi: 10.2779/75203

3. MAES Technical Report, EU, Mapping and Assessment of Ecosystems and their Services: Mapping and assessing the condition of Europe's ecosystems: Progress and challenges, 2016-095; ISBN 978-92-79-55019-5, doi:10.2779/351581

4. Kostov, G., Rafailova E., Vassilev V., Bratanova- Doncheva S., Gocheva K., Chipev N., Methodology for assessment and mapping of woodland and forest ecosystems condition and their services in Bulgaria, 2017, ISBN 978-619-7379-07-5.

5. Lawley V. et al., Site-based and remote sensing methods for monitoring indicators of vegetation condition: An Australian review, Ecological Indicators 60 (2016) 1273-1283, http://dx.doi.org/10.1016/j.ecolind.2015.03.021
6. Tuominen J., Lipping T., Kuosmanen V. and Haapanen R., Remote Sensing of Forest Health, Geoscience and Remote Sensing, Pei-Gee Peter Ho (Ed.), 2009, ISBN: 978-953-307-003-2, InTech, http://www.intechopen.com/books/geoscience-andremote-sensing/remote-sensing-of-foresthealth

7. Pavlova, A., R. Nedkov, Application of the different vegetation indexes regarding to forest physiology and climatic seasons, Scientific Conference "Space, Ecology, Safety" with International Participation, 10-13 June 2005, Varna, Bulgaria SES‘ 2005, 263-268.

8. Körner Ch. and Paulsen J., A world-wide study of high altitude treeline temperatures, Journal of Biogeography, 31, 2004, 713-732.

9. Tucker C.J., Red and Photographic Infrared Linear Combinations for Monitoring Vegetation. Remote Sensing of Environment, 8, 1979, 127-150. doi: http://dx.doi.org/10.1016/0034-4257(79)90013-0

10. Tucker C.J. and Sellers, P.J., Satellite remote sensing of primary production, Int. Journal of Remote Sensing, 1986, vol. 7, 11

11. Nedkov R., "Normalized differential greenness index for vegetation dynamics assessment", Comptes rendus de l'Acad'emie bulgare des Sciences, 70, 8, Prof.Marin Drinov Publishing House of Bulgarian Academy of Sciences, 2017, 1143-1146, ISSN:1310-1331.

12. Nedkov R., Orthogonal transformation of segmented images from the satellite Sentinel-2, Comptes rendus de l'Acad'emie bulgare des Sciences, 70, 2017, 5, 687-692.

13. http://spirits.jrc.ec.europa.eu/?page $\mathrm{id}=184$

\section{ИЗПОЛЗВАНЕ НА ДИСТАНЦИОННИ МЕТОДИ ЗА ОЦЕНКА НА АКТУАЛНОТО СЬСТОЯНИЕ НА ВИСОКОПЛАНИНСКИ ЕКОСИСТЕМИ (ЮГОЗАПАДНА РИЛА ПЛАНИНА - БЪЛГАРИЯ)}

Костадин Катранджиев

Резюме: На базата на мултиспектрални спътникови данни от Sentinel 2 е извършена оценка на актуалното състояние на високопланинските екосистеми в избрани територии на югозападна Рила планина. За определяне на актуалното състояние на високопланинските екосистеми са изчислени стойностите на Нормиран разликов вегетационен индекс (NDVI), Нормиран разликов воден индекс (NDWI) и Нормиран разликов индекс на зеленост (NDGI). Получените стойности на индексите са представени във вид на графики и тематични карти, показващи пространственото разпределение на актуалното състояние на екосистемите във високите части на Рила планина. Получените резултати могат да бъдат използвани за оценка на екосистемни услуги, предоставяни от посочените екосистеми.

Ключови думи: горски екосистеми, дистанционни изследвания, NDVI, NDWI, NDGI

\section{Kostadin Katrandzhiev, PhD Student}

Institute of Biodiversity and Ecosystem Research at the Bulgarian Academy of Sciences

2, Gagarin Str.,

Sofia 1113, Bulgaria

Phone: +359899169870

e-mail: kmkatrandjiev@gmail.com

\author{
Костадин Катранджиев, докторант \\ Институт за биоразнообразие и екосистемни \\ изследвания - БАН \\ ул. „Ю. Гагарин“ 2 \\ София 1113, България \\ Тел.: 0899169870 \\ e-mail:kmkatrandjiev@gmail.com
}

